\title{
OPERATION OF THE AUDITORY FEEDBACK MONITORING LOOP IN CHILDREN WITH ARTICULATORY DEFECTS
}

\author{
SANDRA OSSIP, B.A. LoG. (RAND)
}

\section{INTRODUCTION}

Audition serves as the principle controlling unit in the speech servosystem, the motor aspect being subject in a large part, to the command of audition. From studies carried out on the deaf and hard-of-hearing population, such as that of Carr, ${ }^{1}$ it is apparent that although normal hearing and auditory defective infants have many similarities in their early vocalizations, they develop aberrant speech patterns. Chase ${ }^{3}$ quoted other types of clinical cases, such as those with somesthetic sensory deficits, and concluded that both acoustic information about speech and intact feedback are relevant in the normal acquisition of speech, and lead, according to Chases' hypothesis, to neurophysiological organization which underlies the ability to speak. The motor and sensory systems, and the interaction between the two, are necessary for the development of verbal behaviour.

A closed-loop control system exists when the system can operate to control the machine of which it is a part, and is error-sensitive, error-measuring, self-adjusting and goal directed. In contrast, an openloop system would not be able to measure the output and make adjustments, if the results are not those desired. Mysak ${ }^{8}$ was one of the first to hypothesize the development of closed internal and external audiovocal and audioverbal loops as the components of the speech system.

In this study project the writer is concerned with the internal monitoring feedback loop, but information about the development of this, particularly the auditory feedback monitoring system for speech, is rather scant. The studies carried out to date have assumed, as Fairbanks ${ }^{4}$ did, that the closed-loop auditory feedback monitory system can be inferred from the disturbances in speech produced by an experimental technique which delays the air conducted feedback to the speaker's ears, i.e. Delayed Auditory Feedback (DAF). Studies done by Yeni-Komshian, ${ }^{12}$ Chase, ${ }^{3}$ MacKay ${ }^{7}$ and Chase et al. ${ }^{2}$ suggest that older children show greater DAF effects than younger children, indicating that in younger children, the monitoring loop is still in the process of being closed and the motor organization of speech incomplete or still under practice.

When considering the importance of sensation in this loop system and in the consequent acquisition of speech, disregarding the motor mecha- 
nisms which may be inadequate, defective speech could arise from a defective model which guides the output, or, from a failure of this mechanism which compares the output with the intended or desired production.

Within the cybernetic framework adopted here, aspects such as auditory memory span and phonetic discrimination defects can be considered as "substandard functioning of some component of the speech servo-mechanism" which may be possible because of many functional articulatory disorders. ${ }^{5}$ Here it is assumed that the defect arises from a failure of the comparative mechanism from which the original auditory image or model had to be derived. Because of the significance of maturation of the ability to articulate, another aspect must be considered. This is the possibility that the loop control system in children with articulation disorders, has not been closed and does not have the properties of "monitoring" the output.

\section{EXPERIMENTAL METHODOLOGY}

\section{AIM}

The purpose of this experiment is to determine whether the auditory feedback monitoring system for speech is operative in children with multiple articulatory errors. This assessment was done by mechanically inducing an interference in the air conducted loop and studying the effects on a sample of the above-mentioned population as compared to the effects on a normal population-sample. The hypothesis thus being that the children with articulatory disorders will show less severe breakdown under delayed auditory feedback than children with no articulatory defects.

\section{METHOD}

\section{SUBJECTS}

The ages of the subjects ranged from four years seven months to nine years five months; six of the children were males and four females. The experimental group consisted of three males and two females who were known to have two or more articulatory errors. The control group consisted of five subjects who were pair matched with the experimental group on the following variables:

(a) Sex.

(b) Age.-The subjects were matched to have equal ages within approximately three months.

(c) Educational Level.-The controls were taken from the same classes as the experimental subjects. The subjects taken from a nursery school were in the same group.

(d) Intelligence.-Subjects were not formally tested and matched, but were judged to be "above average" or "average" by the individual class teachers.

(e) Level of Maturity.-Assessed and judged by the class teachers. 
(f) Personality.-No formal tests were administered but children were matched according to teachers' recommendations.

(g) Socio-economic Status.-The children all attended schools which were situated in similar types of areas. They could be assessed to be of middle socio-economic level.

(h) All children had histories of normal speech and hearing development, and apparently normal central nervous systems.

\section{INSTRUMENTATION}

(a) An Amplivox Audiometer (Model 82) was used to establish the air-conduction threshold for each subject.

(b) A National Tape Recorder (Model RQ7065) was used to record all responses made while the subjects were in the experimental situation, and these samples were used for later analysis. The speed for recording was kept constant at $3 \frac{3}{4}$ i.p.s. and recording volume level also remained fixed.

(c) The Madsen (Model BS63) Delay Speech Unit was used to induce the experimental conditions of Normal Auditory Feedback (NAF) and Delayed Auditory Feedback (DAF). The recorder and playback heads were combined, enabling adjustment of delay intervals. The critical interval of 0,2 seconds was used throughout the experiment. The output intensity level was also kept constant. Maico soft cushion headphones were used.

\section{MATERIALS}

(a) The Templin Darley Picture Articulation Test was used and the spontaneous method of eliciting responses was followed. Validity and reliability of the examiner's judgements of articulation were found to be adequate, following appropriate statistical and subjective analysis. Two other therapists independently recorded the same responses.

(b) The material used for two of the three tasks in the experiment consisted of two sets of five cards each (Set A and Set B). The cards contained clear pictures of common every-day objects together with a clearly written representation of them.

(c) Recitation of a Nursery Rhyme.

\section{PROCEDURE}

The experimentation took place in an IAC (Series 1600 ACT) soundproof testing booth where the experimenter established' an air conduction threshold for each ear. The articulation screening test was then administered to assess the subjects' articulatory abilities. After a rest interval, the subject was taken to another soundproof room where the child was settled with the experimenter $E$. The microphone of the tape recorder was placed on the table so that it was able to pick up all the responses elicited from the child. The earphones, which were connected to the Delayed Speech 'Unit, were placed over the child's ears. E presented the first set of cards (Set A) within the child's visual 
field and the subject was asked to name the pictures on the cards. When this was completed to the satisfaction of the $\mathrm{E}$, the child was asked to repeat the naming procedure from the bcginning.

Before the following repetition was commenced, the child was cold of the possibility that his voice "may sound funny". The DAF condition was then commenced. As soon as the child completed the task of naming all five cards, the DAF condition was discontinued. The same procedure was repeated with the second set of cards (Set B) first under the condition of NAF and then DAF.

The final experimental task was then begun, where the subject was required to repeat a nursery rhyme under the two conditions of NAF and DAF.

\section{RESULTS}

\section{ANALYSIS}

After a short pilot study conducted on ten adult subjects under NAF and DAF conditions, and critical evaluation of the information gained on these subjects, the writer felt that the measures which would yield empirical data that could be subjected to analysis would be:

1. Time: The mean rate reduction score was obtained by subtracting the time taken for a task under NAF from the time taken under DAF. Three such scores were obtained for each subject, one for each task.

2 . The second score was a more qualitative measure of the number of words prolonged under DAF. The experimenter judged these, after finding that two judges' (Speech Therapists) evaluations agreed with her's. A percentage score was obtained for each subject on the two sets of cards. Percentage of words prolonged $=$ Number of words prolonged $\times 100$.

3. Observation of the subjects during the experimental situation. Their reactions and verbal responses were recorded by the experimenter.

\section{METHOD OF ANALYSIS}

1. The time scores (in seconds) were recorded and summaries were compiled allowing for comparison between the experimental and control groups.

2. The time scores obtained for task three (the nursery rhyme) were subjected to a test of significance. The student " $\mathrm{t}$ " test was applied to see if the differences between the two groups were significant.

3 . The mean percentage prolongation scores obtained for each group were subjected to a similar " $t$ " test analysis.

4. A graph was drawn to represent the age-link hypothesis. The percentage prolongation of the subjects in the experimental group was used, where each subject represented a different age level.

\section{DISCUSSION}

Under conditions of DAF, all the "normal" subjects or those having no articulatory errors, broke down considerably in comparison to their 
performance under NAF. In contrast, under similar conditions, the experimental group showed less impairment of their natural speech and voice.

The most marked change in speech, was the increase in time taken to produce the same speech sample under DAF than under NAF. These scores, together with the mean prolongation scores (Tables 1 and 2) revealed that there were significant differences between the two samples of the population at the $15 \%$ level of confidence.

\begin{tabular}{l|lr|rr|c}
\hline Subjects & $\begin{array}{l}\text { Reduction Score } \\
\text { Control Group I }\end{array}$ & $\begin{array}{c}\text { Reduction Score } \\
\text { Experimental } \\
\text { Group II }\end{array}$ & $\begin{array}{c}\text { Difference between } \\
\text { Reduction Score } \\
(I-I I)\end{array}$ \\
\hline Pair 1: $(\mathrm{CA}=4.6$ years) & $\mathrm{C} 1$ & 38 & $\mathrm{E} 1$ & 4 & 34 \\
\hline Pair 2: $(\mathrm{CA}=6.3$ years $)$ & $\mathrm{C} 2$ & 22 & $\mathrm{E} 2$ & 19 & 3 \\
\hline Pair 3: $(\mathrm{CA}=6.7$ years $)$ & $\mathrm{C} 3$ & 28 & $\mathrm{E} 3$ & 13 & 15 \\
\hline Pair 4: $(\mathrm{CA}=7.5$ years $)$ & $\mathrm{C} 4$ & 5 & $\mathrm{E} 4$ & 11 & 6 \\
\hline Pair 5: $(\mathrm{CA}=9.5$ years $)$ & C5 & 14 & E5 & 10 & 4 \\
\hline
\end{tabular}

Significant at the $.001 \%$ level.

Table 1: Summary of the mean reduction scores of Task Three

\begin{tabular}{l|lr|rr|c}
\hline \multicolumn{1}{c|}{ Subjects } & $\begin{array}{c}\text { Number of } \\
\text { Prolongations } \\
\text { Control Group I }\end{array}$ & $\begin{array}{c}\text { Number of } \\
\text { Prolongations } \\
\text { Experimental } \\
\text { Group II }\end{array}$ & $\begin{array}{c}\text { Difference between } \\
\text { Prolongations } \\
(I-I I)\end{array}$ \\
\hline Pair 1: (CA $=4.6$ years) & C1 & 7 & E1 & 0 & 7 \\
\hline Pair 2: (CA $=6.3$ years) & C2 & 4 & E2 & 2 & 2 \\
\hline Pair 3: (CA $=6.7$ years) & C3 & 2 & E3 & 2 & 0 \\
\hline Pair 4: $(\mathrm{CA}=7.5$ years) & C4 & 3 & E4 & 3 & 0 \\
\hline Pair 5: $(\mathrm{CA}=9.5$ years) & C5 & 6 & E5 & 3 & 3 \\
\hline
\end{tabular}

Significant at the $10 \%$ level.

Table II: Summary of the Mean Prolongation Scores on Tasks One and Two

The results indicate that the auditory feedback monitoring loop system is not operating at the same level or is still in the process of being "closed" in the child with functional articulatory defects compared to the child with normal speech.

It appears that Chase's ${ }^{2}$ hypothesis, which states that the auditory feedback monitoring system for speech develops as a function of age, 
is borne out in these results (see Figure 1). It was noted that a subject of four years shows less marked behavioural disturbance under DAF than subjects of nine years of age. The children in the 6-7 years age group do appear to fall between the two extremes on the continuum.

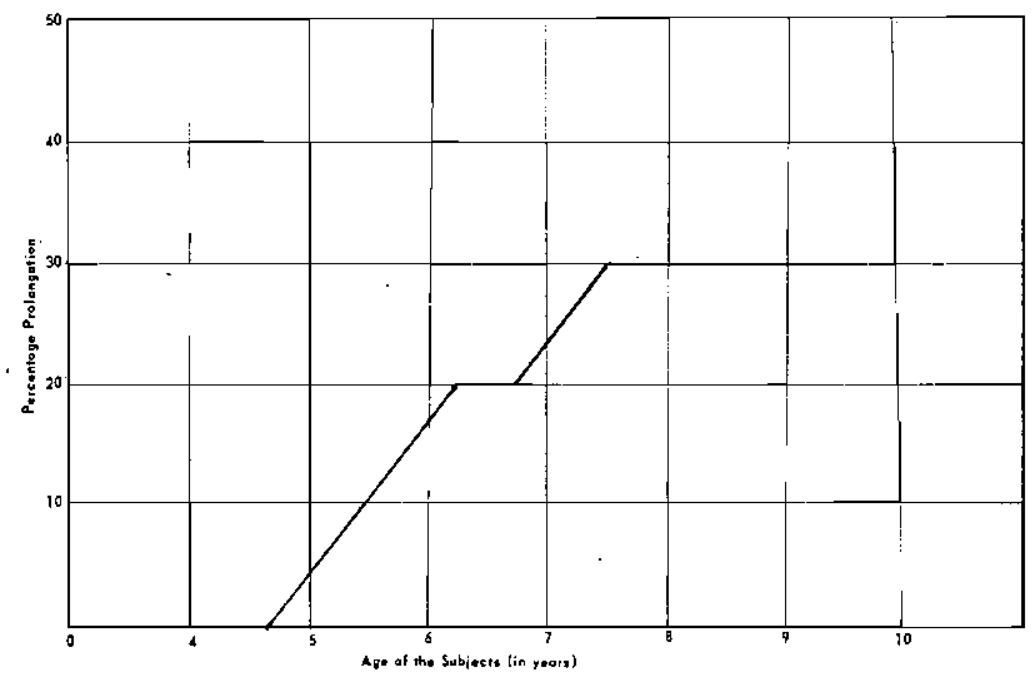

Figure: The Percentage of Breakdown in the Experimental Group, Measured by Prolongations as a Function of Age.

It can thus be assumed that the speech system develops from an open external audio-vocal loop to form a closed audio-verbal loop. This is the most complex form of behaviour as it is the ability to monitor, to check the output and to change it if necessary.

Under DAF, the sensory information and the motor output are out of phase, and this results in a disruption of speech, as there is an interruption in the temporal pattern of motion. If a person regulates his behaviour continuously, there will be a marked effect on his speech under DAF. If, however, the temporal patterning is not as organized or practiced, the disruption will not be as severe, as the loop is not a closed monitoring circuit Thus the child with articulatory disorders appears to be immature in the development and acquisition of speech. It appears from this project that sensory information is as relevant to speech development as is the motor aspect. Auditory feedback consequently appears to play an important role in the process of speech acquisition.

The writer has in this study continually stressed the importance of sensory feedback for adequate motor function, but it would be an oversimplification to say that the organism functions as a computer, and treat him as a simple control system. She has assumed the basic hypothesis that the individual possesses the control properties of a cybernetic system, but as a living system, exhibits flexibility and change in pattern of control. 
One of the most complex forms of behaviour is verbal communication, which emerges in the context of active exchange of acoustic information that ultimately results in the development of a system of speech motor gestures that conforms to the system utilized by the adult culture.

Some therapeutic procedures have been devised by therapists such a: Mysak $^{8}$ and Van Riper and Irwin", but the writer feels that not enough emphasis is placed on audition as being the major source of sensory feedback information. She advocates use of increased auditory stimulation, auditory training techniques, and the use of the auditory training aid (train-ear) in order to develop the auditory feedback monitoring system for speach. The therapist, at first, is the monitor, and eventually the child can exercise automatic control. In a similar manner other speech disorders can be attributed to breaks in the cybernetic feedback systems and therapy programmes be devised.

An implication of the above theorising that has not been fully discussed is the classification of function in the structure of the nervous system. One assumption that is important is that the stream of speech is activated and controlled by a multiple determined plan and intention of communication, by antecedent and simultaneous internal and external events, by intention and organization of the message and by further sets of instructions that activate and control the movements that convert the message into sound. This assumption leads to an auxiliary statement that disorganization of the motor aspects of speech behaviour results from a variety of lesions. Aphasia results from interference that disrupts both analysis and integration of verbal messages as the analysis and integration of language requires continuous and dynamic discriminatory and feedback activity. Schuell et al. ${ }^{10}$ advocated her aphasic therapy on the above assumptions. Her principles stress the need to provide the patient with adequate feedback by giving him adequate and increased stimulation. The patient depends on the therapist or a machine for feedback until he is able to regulate his behaviour in terms of his own feedback.

Mecham $^{6}$ considered apraxia with this framework. Apraxia refers to a disorder in the motor functioning in which "the individual has a basic motor capability to perform a motor act, but is unable to plan the act at an identical level, or transpose a visual impression into an appropriate motor counterpart or sequence". He viewed apraxia as a "distorted or unstable or nonvaried reafterent feedback' and the disruption of visual perceptual function in terms of failurés or retardation of central organization". The training of these children and other braininjured children is orientated towards facilitating basic processes of general neurological organization, establishing or enhancing intermodal sensory integration, and to help clarify or define the child's sensory motor interaction. The child with: "functional articulatory errors" can be seen to have a similar defect though there is no known central nervous system involvement. 
Implications from this can be extended to problems encountered in teaching speech to the deaf child. Here there is definite auditory sensory deprivation. The writer feels that it is necessary not only to provide the child with a complete representation of the adult speech models to allow them to be reproduced, but it is also necessary to provide this information in a form that allows the child to match his speech with the adult speech, and compute the degree of approximation necessary to make systematic alterations directed at minimizing the mismatch between the two.

The cybernetic interpretation of the developmental literature, taking into account the closed-loop nature of the behaviour and its selfregulating characteristics, suggests some ideas about teaching and training in general. The two main principles developing are: that the individual at all ages should be aided in gaining control over his own actions, and that teaching of specific skills must be adjusted to the phase of development of the feedback-control mechanism. Teaching and training design should be adjusted to the level of control already achieved and also should be sensitive to the potential changes in response organization that may come in time through maturation.

\section{SUMMARY}

This study constitutes a preliminary evaluation of the utilization of auditory feedback for the acquisition of normal speech in normal speaking children and children having functional articulatory errors. The degree to which this is utilized for the organization and control of motor activity was inferred by delaying auditory feedback in time and quantitating the resulting disturbances in the speech behaviour.

Evidence was found to support the following hypotheses:

1. There is a breakdown of speech under DAF.

2: Children with multiple articulatory disorders exhibit less severe breakdown effects under DAF than their normal peers.

3. There appears to be a strong relationship between increasing age and articulatory ability.

4. There tends to be a relationship between increasing age and the breakdown of speech under DAF.

5. Monitoring of speech is a highly skilled control system which tends to develop with age and experience, and is not operating as strongly in the child with articulation defects.

From the results of the study, it seems that the auditory feedback monitoring loop for speech is not operating as successfully in the child with multiple articulatory errors as it operates in the normal child, and that the development of a closed loop system appears to be retarded in some way.

\section{OPSOMMING}

Hierdie studie vorm 'n voorbereidende evaluasie van die benutting van ouditiewe terugvoering vir die verwerwing van spraak in normaal- 
sprekende kinders en kinders mel funksionele artikulasiefoute. Bewyse is verkry om die volgende hipoteses te ondersteun:

1. Daar is ' $n$ afbraak van spraak tydens vertraagde ouditiewe terugvoering.

2. Kinders met veelvoudige artikulasieafwykings vertoon minder ernstige afbraakeffekte tydens vertraagde ouditiewe terugvoering as hul normale maats.

3. Daar blyk 'n sterk verhouding te wees tussen ouderdomsverhoging en artikulatoriese vermoë.

4. Daar is 'n neiging tot ' $n$ verhouding tussen ouderdomsverhoging en die afbraak van spraak tydens vertraagde ouditiewe terugvoering.

5. Aktiewe kontrolering van spraak is 'n hoogs ontwikkelde sisteem wat neig om te ontwikkel met ouderdom en ondervinding. Dit blyk ook nie so aktief te wees in die kind met artikulasieafwykings nie.

Uit die resultate verkry van hierdie studie wil dit voorkom asof die kontrolebaan van die ouditiewe terugvoering van spraak nie so effektief werkende is in die kind met veelvoudige artikulasie foute as in die normale kind van dieselfde ouderdom nie. Die ontwikkeling van 'n geslote baansisteem blyk op een of ander wyse vertraag te wees.

\section{REFERENCES}

1. Carr, J. (1953): An investigation of the spontaneous speech sounds of the five-year-old deaf born child. Journal of $S$ peech and Hearing Disorders, 18, 22-29.

2. Chase, R. A., Sutton, S., First, B. and Zubin, J. A. (1961): A developmental study of changes in behaviour under delayed auditory feedback. Journal of Genetic Psychology, 99, 101-112.

3. Chase, R. A. (1967): Motor organization of speech. Annual report. Johns Hopkins University School of Medicine, Baltimore, Maryland, 103-145.

4. Fairbanks, G. (1955): Selective effects of delayed auditory fecdback. Journal of Speech and Hearing Disorders, 20, 333-345.

5. Mange, C. N. (1960): Relationship between selected auditory perceptual factors and articulation ability. Journal of Speech and Hearing Research, 67-74.

6. Mecham, M. J. (1966): Introduction-Nature and Scope of the Problem in Communication Training in Childhood Brain Injury. Charles C. Thomas. Illinois.

7. MacKay, D. G. (1968): Metamorphosis of a critical interval: Age-linked changes in the delay in auditory feedback that produces maximal disruption of speech. Journal of the Acoustic Society of America, 43, 811-821.

8. Mysak, E. D. (1966): Speech Pathology and Feedback Theory. Charles C. Thomas. Springfield, Illinois.

9. Reef, H. (1968): Lecture notes in "Neurology" given to Speech and Hcaring Therapy students.

10. Schuell, H., Jenkins, J. J. and Jimenez-Pabon, E. (1967): Aphasia in Adults. Harper and Row, Inc., New York.

11. Van Riper, C. and Irwin, J. N. (1959): Voice and Articulation. Pitman Medical Publishing Co., London.

12. Yeni-Komshian. G. (1968): The development of auditory feedback monitoring: No. 2. Delayed Auditory Feedback Studies on the speech of children between 2 and 3 years of age. Journal of Speech and Hearing Research, 1 , 307-315. 